\title{
An Application of Hedonic Regression to Evaluate Prices of Polish Paintings
}

\author{
Dorota Witkowska
}

Published online: 2 May 2014

(C) The Author(s) 2014. This article is published with open access at Springerlink.com

\begin{abstract}
As the global financial crisis hit the world-wide stock markets, investors looked for alternative investments to diversify their portfolios. One of the more attractive alternate investment opportunities has been investment in art. However, in order to consider artworks as investment assets, the performance of the artworks must be evaluated in order to compare it to other financial instruments. Therefore, hedonic art price indexes are constructed for different art markets. The art market in Poland is characterized by a limited scale since it has only been developing since 1989. The aim of our research is evaluation of the hedonic art price indexes for Polish paintings. Hedonic regression models are estimated using data from auctions of paintings that took place in Poland in the years 2007-2010.
\end{abstract}

Keywords Art market · Hedonic regression · Price index

JEL $\mathrm{C} 10 \cdot \mathrm{F} 39$

\section{Introduction}

The global financial crisis hit worldwide stock markets and the financial market situation made investors look for alternatives (i.e. investments other than stocks, bonds or cash) to diversify their portfolios. One attractive alternative investment opportunity in the financial market was investment in art. Thus, there is growing literature in arts and investment: Frey and Pommerehne (1988, 1989a, b), Pesando (1993), Chanel et al. (1994), Mei and Moses (2002), Worthington and Higgs (2003, 2004), Campbell, (2004, 2008), Hsieh et al. (2010), Higgs (2012) and Frey and Cueni (2013), among others.

The majority of publications refer to well-developed art markets. However, the existence of "emerging" markets was already noted by Kraeussl and Logher (2010). The art market in Poland is limited in scale as it has only been developing since 1989, when the transformation of the economic system began. During the communist regime,

D. Witkowska $(\bowtie)$

University of Lodz, Lodz, Poland

e-mail: prof.witkowska@gmail.com 
the level of life and everyday living problems did not allow Polish society to create demand for artworks similar to the one in Western Europe. However, even in that time there were individuals who could collect art and afford even high pieces. The past two decades were characterized by changes in income distribution and the structure of consumption that caused the increased interest in the art market in Polish society.

The aim of this paper is to describe the art market in post-communist Poland and to discuss the results of our investigation concerning construction of the art price index for Polish paintings. The hedonic art price indexes are evaluated on the basis of hedonic regressions which are estimated using data from auctions of paintings held in Poland in the years 2007-2010.

\section{Art as a Financial Instrument}

Renneboog and Spaenjers (2013), using data from more than a million auction trades and 10,100 artists that took place in the period 1900-2007, show that return for art is only $4 \%$ per year while stocks yield a return over $6.5 \%$. But art investment is more profitable than government bonds and gold, which yield returns of 2-3\% and are comparable to corporate bonds that give $4 \%$ average annual returns. However, risk measured by standard deviation is higher for gold (more than $24 \%$ ) than for art $(10 \%)$, equities (16.5\%), government bonds (less than $11 \%$ ) and corporate bonds (9.5\%). Regardless, according to the presented results, investment in art seems to be a comparatively safe asset class that can serve as a hedging instrument against inflation and possibly diversify the investment portfolio, since art is not correlated with equities or bonds but associated with tangible assets like gold or commodities.

There are several features that are characteristic for works of art. (1) Current market value is difficult to evaluate since there is no "natural value," which could be used as reference for fair value (Goetzmann et al. 2011). (2) Art investments are undivided and not liquid. (3) Artworks are often expensive, as the cost of purchase and sale may be high ( 10 to $25 \%$ of the sale price is the hammer price while costs on financial markets are about $1 \%$ of the sale price). Regardless of the risk of price variability of investment instruments, there are also several risks specifically for the art market (Frey and Cueni 2013): (a) The buyer can never be certain whether the purchased object is original (i.e. not a copy or forgery). (b) The buyer must take into account the quality of paintings that have been repainted, damaged, not properly renovated, or stored in ways that affect the decline of their values. (c) Owners of art pieces can be afraid that the masterpieces might be stolen or destroyed. (d) Tastes and fashions change over a time and the art market is characterized by extreme heterogeneity; thus, one never knows if a certain artist will not "fall out of fashion" in the future. ${ }^{1}$ (e) Art belongs to the group of luxury goods and its prices are very sensitive to the general economic situation and income changes.

\footnotetext{
${ }^{1}$ Renneboog and Spaenjers (2013) report 220 "fallen out of fashion" artists who were included in the 1926, 1959 and 1980 editions of Gardner's Art through the Ages but not in the 1996 or 2004 editions.
} 


\section{Art Market in Poland}

The beginning of the art market in Poland spans the years 1840-1850. However, the real development of that market was observed at the end of the nineteenth century until World War II (WW II). In pre-war Polish cities, particularly in Warsaw and Cracow, people were intensely interested in art. Collecting art was one of the factors that indicated one's social status. The looting of Polish cultural artifacts was carried out by Nazi Germany and the Soviet Union during WWII, and by the latter also some years after. A significant portion of Poland's cultural heritage, estimated at about half a million art pieces, was plundered by the occupying powers. The estimated value of war losses is 30 billion US dollars (Radwan 2004). Pieces are still occasionally recovered and returned to Poland; however, it is a very complicated process.

Under the communist system after World War II, the art market in Poland practically did not exist. In that time several art galleries and artist associations were operating, buying and selling art pieces mostly produced by domestic artists or artists from other Soviet bloc countries. During the communist regime, all artworks and crafts that had been produced before 1945 were subjected to "special interest by the state" and they were treated as part of the national heritage, so it was possible to trade without any restrictions for post-war and contemporary art only. At that time folk art was especially appreciated.

The art market in Poland started to normalize and develop at the beginning of the political and economic transformation in 1989. New art galleries and foundations have been created together with auction markets. In the years 1989-2012, the number of art auctions increased from 8 to 122 (Gajewski and Potocki 2013, p. 13).

Analysis of the Polish art market in terms of medium is presented in Table 1. It is observed that paintings are the most popular works of art in comparison to other forms of art, both in terms of number of pieces sold (56\%) and value of transactions (72\%). In 2012, the Polish art market value was estimated for 300-350 million PLN ${ }^{2}$ (approximately about 75-90 million euros), while auction sales were 60.5 million PLN. ${ }^{3}$ It was the highest result since 1989. The structure of the Polish art market is presented in Table 2. The term "ultra-contemporary" is used for young artists (under 40 years old).

According to the Deloitte (2013) report, the average annual return from 800 repeat sales that took place in Poland during the last 20 years was $25.7 \%$, while at the same time equity returns measured by Warsaw Stock Exchange Index WIG20 was only $8.7 \%$. ${ }^{4}$ Annual returns from artworks held longer than 15 years was $46.6 \%$, while investments within the horizon shorter than 5 years gave only $0.2 \%$ profit. Thus the time spam of investments is crucial in obtained returns.

\footnotetext{
${ }^{2}$ See: World Wealth Report 2012. The world art market global sales equaled 43 billion euros in 2012 (Mc Andrew 2013), therefore the Polish art market is about $0.2 \%$ of the world sales. PLN-Polish currency. ${ }^{3}$ The Deloitte (2013) report is a part of the Art and Finance Survey 2012 (www.deloitte.com/lu/ artandfinance).

${ }^{4}$ See (Gajewski, Potocki, 2013).
} 
Table 1 Structure of Polish art market in the first half of 2012 by mediums

\begin{tabular}{lllllr}
\hline Mediums & $\begin{array}{l}\text { Lots } \\
{[\%]}\end{array}$ & $\begin{array}{l}\text { Value } \\
{[\%]}\end{array}$ & Mediums & $\begin{array}{l}\text { Lots } \\
{[\%]}\end{array}$ & $\begin{array}{r}\text { Value } \\
{[\%]}\end{array}$ \\
\hline Sculpture & 2 & 1 & Graphic & 14 & 2 \\
Photography & 1 & 0 & Drawing & 17 & 20 \\
Arts \& Crafts & 10 & 5 & Painting & 56 & 72 \\
\hline
\end{tabular}

Source: Own elaboration on the basis of data from Gajewski and Potocki 2013, pp. 18-19

\section{Methodology}

Two estimation methods are commonly used to construct art price indexes: repeat-sales regression and hedonic regression (Ginsburgh et al. 2006, p. 947). The limited scale of the art market in Poland does not allow application of the repeated sale approach for the price index construction, therefore the hedonic approach is employed.

Artworks are heterogeneous assets with a variety of physical and non-physical characteristics that make them unique and important for the buyers, including the artist's reputation, materials used, the period of production, and subjective traits like quality. Therefore, the price of an artwork depends on these characteristics. The hedonic approach allows us to estimate the value attached to each one of the attributes that are deemed to be significant in the determination of the price and to evaluate the price index $\left(H I_{t}\right)$ with the hedonic quality adjustment $\left(H Q A_{t}\right)^{5}$ :

$$
H I_{t}=\frac{N I_{t}}{H Q A_{t}}=\frac{\prod_{i=1}^{n}\left(P_{i, t}\right)^{1 / n} / \prod_{i=1}^{m}\left(P_{i, t-1}\right)^{1 / m}}{H Q A_{t}}
$$

where $P_{i, t}$ represents the price of the artwork $i$ at the time $t$, and:

$$
H Q A_{t}=\exp \left[\sum_{j=1}^{k} \widehat{\alpha}_{j}\left(\sum_{i=1}^{n} \frac{X_{i j, t}}{n}-\sum_{i=1}^{m} \frac{X_{i j, t-1}}{m}\right)\right]
$$

where $X_{i j, t}$ is an observation of the $j^{\text {th }}$ characteristic of the artwork $i$ at the time $t, n$ and $m$ are numbers of lots sold in the period $t$ and $(t-1)$ respectively, $\widehat{\alpha}_{j}$ is parameter estimate standing by the $j^{\text {th }}$ variable in hedonic regression (pooled regression) that usually takes the following form:

$$
\ln P_{i, t}=\alpha_{0}+\sum_{j=1}^{k} \alpha_{j} X_{i j, t}+\sum_{t=1}^{\tau} \beta_{t} Z_{i, t}+\varepsilon_{i, t}
$$

where $\alpha_{j}$ reflects the coefficient value (or implicit price) of the characteristic $X_{j}, Z_{i, t}$ reflects the time dummy, which takes the value 1 if the $i^{\text {th }}$ painting is sold in the period $t$ and takes the value 0 otherwise, and $\varepsilon_{i, t}$ represents the disturbance term.

\footnotetext{
${ }^{5}$ Hedonic price indexes are described by Nesheim (2006) and Triplett (2006), while their applications to the art market are discussed by Candela et al. (2004), Kraeussl and van Elsland (2008), Kraeussl and Wiehenkamp (2012), to mention some research provided for developed art markets.
} 
Table 2 Structure of the Polish auction market in 2012 by segments

\begin{tabular}{llc}
\hline Segments & Lots [\%] & Value [\%] \\
\hline Post-war and contemporary & 30 & 31 \\
Ultra-contemporary & 44 & 8 \\
Art before 1945 & 26 & 61 \\
\hline
\end{tabular}

Source: Own elaboration on the basis of data from Gajewski and Potocki 2013, p. 14

One of the underlying assumptions is that the price of an artwork depends essentially on its quality, which is to a great extent quantifiable. Therefore, the parameter estimates $\widehat{\alpha}_{j}$, from the model (3), are used to evaluate a hedonic quality adjustment (2). The explanatory variables in hedonic models constructed for the art price usually describe the artist's and the exhibitor's reputations, the type and quality of the artwork, and the conditions of the transactions. All auctions relating to an artist are included in the calculation in order to avoid selection bias.

The numerator in (1) can be treated as the naive price index $\left(N I_{t}\right)$, since it describes the so-called "average painting" (Candela et al. 1997) from the aggregation of all artworks that create the sample representing the art market or its segment:

$$
N I_{t}=\frac{\prod_{i=1}^{n}\left(P_{i, t}\right)^{1 / n}}{\prod_{i=1}^{m}\left(P_{i, t-1}\right)^{1 / m}}
$$

Since there is no fixed recipe for the regression (3) construction, it may contain different sets of explanatory variables selected by the model constructor. Different specification of the hedonic model causes changes in the hedonic quality adjustment (2) and, in consequence, different values of the hedonic index. Therefore, we may evaluate an average hedonic index defined as:

$$
A H I_{t}=\sqrt[\mathrm{K}]{\prod_{k=1}^{K} H I_{t, k}}=\frac{N I_{t}}{\sqrt[\mathrm{K}]{\prod_{k=1}^{K} H Q A_{t, k}}}=\frac{N I_{t}}{A H Q A_{t}}
$$

where $H I_{t, k}, H Q A_{t, k}$ denote hedonic indexes (1), and quality adjustment (2) evaluated for the $t^{\text {th }}$ period on the basis of the $k^{\text {th }}(k=1,2, \ldots, K)$ hedonic model; respectively, $A H Q A_{t}$ represents average hedonic quality adjustment.

Having price indexes describing price relationship in two neighboring periods $t$ ( $t=$ $1,2, \ldots, T)$, i.e. $I_{1}, I_{2}, \ldots, I_{t}$, we may calculate the price index $T I_{t}$ concerning price changes in comparison to the first $(t=0)$ period of analysis, i.e.: $T I_{t}=I_{1} \cdot I_{2} \cdot \ldots \cdot I_{t}$. The total index $T I_{T}$ especially informs about price movements during the whole period of investigation since it is the relationship of prices in the last period $t=T$ in comparison to the first period $t=0$. Then, changes of prices from period to period equal $C_{t}=\left(I_{t}-1\right)$. $100 \%$, while price movements in every moment in comparison to the first period of analysis equal $T C_{t}=\left(T I_{t}-1\right) \cdot 100 \%$. In other words, $C_{t}$ informs about returns for every single period while $T C_{t}$ refers to returns obtained in the period from $t=0$ to $t$, and $T C_{T}$ is the cumulative return in the whole period. It is also possible to evaluate the average 
return for the single period, taking into account the total returns from the whole period of investigation, employing geometric mean:

$$
G M=\sqrt[\mathrm{T}]{\prod_{t=1}^{T} I_{t}}=\sqrt[\mathrm{T}]{T I_{T}}
$$

In such a case average return in the single period equals:

$$
G=(G M-1) \cdot 100 \%
$$

\section{Data and Variables Description}

In our research we employ data from auctions of paintings that took place in Poland in the years 2007-2010. In our database ${ }^{6}$ there are 10,400 paintings produced by 2,938 artists, the majority classified as Polish painters whose artworks were produced no earlier than the 19th century, although a great number of the works were painted in the second half of the twentieth century. The total turnover was about 37.4 million euros, and the average value of a transaction was 3.6 thousand euros. In the period 2007-2009, the number of transactions was comparable, although the highest value of transactions was observed in 2008 (see Table 3).

In our research we use a sample of artworks, with Polish paintings representing the biggest segment of the art market in Poland (see Table 1). The sample consists of works painted by the artists who are selected according to the biggest number of lots sold in the investigative period, containing 750 paintings produced by 11 painters sold for 26.76 million PLN (the list of painters with basic characteristics is presented in Table 6 in Appendix). This sample covers $7.2 \%$ of all lots and $16.2 \%$ of the turnover registered in the data base.

In our investigation we use several explanatory variables describing either intrinsic characteristics of the artwork or variables related to the sale. Auction house describes the reputation of the auctioneer. This variable is specified as 9 dummies defined as "name of auctioneer." The reference variant of this variable is: other auctioneers. Artist reputation is defined by the name of a painter that is represented by the variable artist (with 11 variants), and Wyczółkowski is the reference painter. The artist's living status is also often incorporated to hedonic models, as when an artist dies production stops and prices may rise. We assume that the variable living status equals 0 if artist is still living. Type and quality of the art piece is defined by several variables such as: signature, technique and surface of the painting. Technique and materials describe the type of work and this variable is specified as 9 dummies that indicate whether the art piece represents certain types of work. The reference variant of the variable is: other techniques. Signature is one of the artworks attributes, equaling 1 if signature is visible. Surface $\left[\mathrm{cm}^{2}\right]$ of the artwork is the most commonly used variable that describes the physical characteristics of painting. In general the parameter

\footnotetext{
${ }^{6}$ The basic data base was constructed by Lucińska (2012).
} 
Table 3 Database: registered transactions in years 2007-2010

\begin{tabular}{llll}
\hline Year & Number of lots & Value [PLN] & Average value of one transaction [PLN] \\
\hline 2007 & 2,493 & $39,217,845$ & 15,731 \\
2008 & 2,548 & $58,707,150$ & 23,040 \\
2009 & 2,427 & $36,713,800$ & 15,127 \\
2010 & 2,932 & $25,675,900$ & 8,757 \\
Total & 10,400 & $160,314,695$ & 15,415 \\
\hline
\end{tabular}

Source: Own elaboration

estimates for this variable should be positive, however larger works may be difficult to display. Thus in some models squared surface is applied. In the model we use natural logarithms of surface or squared surface area. Conditions of the transaction is represented by two variables: year and price relation. Year of sale is a set of binary variables defined as the year of transaction. The reference variant of this variable is Year_2010. Price relation between reserve and hammer price equals 1 if the former is bigger than the latter, since in such a case a sale might not take place (so-called conditional sale), and 0 otherwise.

\section{Hedonic Regression Models and Price Indexes for Selected Polish Painters}

The procedure of the hedonic price index evaluation consists of three stages: (a) specification and estimation of the hedonic model (3); (b) parameter estimates of the model (3) $\widehat{\alpha}_{j}$ are used to evaluate hedonic quality adjustment (2), and (c) calculation of

Table 4 Comparison of model specifications

\begin{tabular}{|c|c|c|c|c|c|c|}
\hline Hedonic variables & $\mathrm{S} 1$ & $\mathrm{~S} 2$ & S3 & S4 & S5 & S6 \\
\hline Cost & $\bullet+$ & & $\bullet+$ & $\bullet+$ & $\bullet+$ & \\
\hline Year & $\bullet(1)$ & $\bullet(1)$ & $\bullet(1)$ & $\bullet$ & $\bullet$ & $\bullet$ \\
\hline Auction house & $\bullet(4)$ & - (4) & - (4) & $\bullet(7)$ & - (8) & - (7) \\
\hline Artist & $\bullet(9)$ & $\bullet(9)$ & $\bullet(9)$ & $\bullet(9)$ & $\bullet(9)$ & $\bullet(9)$ \\
\hline Signature & $\bullet$ & $\bullet$ & $\bullet$ & $\bullet$ & $\bullet$ & $\bullet$ \\
\hline Technique & $\bullet(5)$ & $\bullet(7)$ & $\bullet(5)$ & $\bullet(2)$ & $\bullet(2)$ & $\bullet(2)$ \\
\hline Price relation & $\bullet$ & $\bullet$ & & $\bullet$ & & $\bullet$ \\
\hline Surface area & $\bullet+$ & $\bullet+$ & $\bullet+$ & & & \\
\hline Surface area $^{2}$ & & & & $\bullet+$ & $\bullet+$ & $\bullet+$ \\
\hline Living status & & & & & & $\bullet+$ \\
\hline$R^{2}$ adjusted & 0.8114 & 0.9964 & 0.8115 & 0.9953 & 0.9953 & 0.9953 \\
\hline$F$ & 101.68 & $6,554.27$ & 105.07 & $4,910.11$ & $5,071.98$ & $4,910.11$ \\
\hline Degrees of freedom & $(32 ; 717)$ & $(32 ; 718)$ & $(31 ; 718)$ & $(32 ; 717)$ & $(31 ; 718)$ & $(32 ; 717)$ \\
\hline Akaike & $1,269.1$ & $1,330.2$ & $1,267.3$ & $-1,492.9$ & $-1,494.4$ & $-1,492.9$ \\
\hline
\end{tabular}

Source: Own elaboration 
the price index due to formula (1). Therefore in the first stage of our research, several hedonic regressions with different sets of variables are estimated. Parameter estimates of selected models are presented in Tables 7 and 8 in the Appendix. The specification of presented models is described in Table 4, where "•" denotes the presence of the certain variable, the number in parenthesis informs about the number of dummies that are statistically significant for multi-variant qualitative features while "+" designates that the influence of certain quantitative or dichotomous qualitative variables is positive and significant (for the significance level 0.05).

The quality of the models can be evaluated using such measures as the adjusted determination coefficient $R^{2}$, t-Student and Fisher statistics, and Akaike information criterion. However, it is difficult to apply these criteria when the model contains dummies describing qualitative features. Likewise, models without constants (i.e. models denoted as S2 and S6) are characterized by determination coefficients close to one because for such models non-centered coefficients of determination are calculated. Among different model specifications, the better one is characterized by smaller information criteria. In other words, models S4-S6 seem to be the best although they differ from others mainly by variable representing surface.

Among distinguished hedonic variables, the artist's living status and surface of the paintings influence positively and significantly the artwork's price in all regression models. Variables artists and auction house are generally significant, although not all variants in one model, and with different signs. Features: signature and price relation are always not significant, while time dummies for year are usually insignificant in presented models.

To evaluate the paintings' price indexes, we assume that all artworks were sold, even if there are some cases when the hammer price was smaller than the reserve price because of a small number of objects in our sample. In Table 5 all indexes (1) and (2), calculated for the models S1, S3, S4 and S6, together with the naive (4) and average (5) indexes are presented. The percentage changes of price indexes according to the reference period that is either the previous year $C_{t}$ or the first year of analysis (i.e. 2007) $-T C_{t}$, together with average annual returns (7) are visible in the last three columns.

One may notice that the hedonic quality adjustment (2) influences the price index essentially since hedonic indexes (1) differ from the naive indexes (4). Also, specification of the hedonic regression (3) plays an important role because we obtained different values of the indexes $H Q A_{t}$ and $H I_{t}$ for each model. These changes are especially visible in the last column containing the average percentage annual changes $G$. In all cases, it is evident that art prices decreased in the year 2010 in comparison to the year 2007, except for indexes calculated for the model S4. ${ }^{7}$ Therefore, it seems useful to calculate average hedonic indexes (5) that are aggregated measures of price movements less affected by single hedonic model specification. In Table 5 the index is calculated from the indexes evaluated on the basis of the hedonic models: S1, S3, S4 and S6.

\section{Conclusions}

The aim of our research is to evaluate hedonic art price indexes for the paintings segment of the Polish art market. In our analysis we consider artists with the biggest

\footnotetext{
${ }^{7}$ Such situations also appeared for different model specifications that are not presented in this paper.
} 
Table 5 Art price indexes

\begin{tabular}{|c|c|c|c|c|c|c|c|}
\hline \multirow[t]{2}{*}{ Type of index } & \multirow[t]{2}{*}{ Year } & \multirow[t]{2}{*}{ Model (3) } & \multirow[t]{2}{*}{$H Q A_{t}(2)$} & \multirow{2}{*}{$\begin{array}{l}\text { Price } \\
\text { index }\end{array}$} & \multicolumn{2}{|c|}{ Changes [in \%] according to } & \multirow{2}{*}{$\begin{array}{l}\text { Annual changes } \\
{[\text { in } \%] G(7)}\end{array}$} \\
\hline & & & & & previous year $C_{t}$ & $2007 T C_{t}$ & \\
\hline \multirow{3}{*}{ Naive (4) } & 2008 & & & 1.4984 & 49.8 & 49.8 & -4.5 \\
\hline & 2009 & & & 0.6163 & -38.4 & -7.7 & \\
\hline & 2010 & & & 0.9441 & -5.6 & -12.8 & \\
\hline \multirow[t]{12}{*}{ Hedonic (1) } & 2008 & $\mathrm{~S} 1$ & 1.4137 & 1.0599 & 6.0 & 6.0 & -3.1 \\
\hline & 2009 & & 0.6867 & 0.8975 & -10.3 & -4.9 & \\
\hline & 2010 & & 0.9860 & 0.9575 & -4.3 & -8.9 & \\
\hline & 2008 & $\mathrm{~S} 3$ & 1.4160 & 1.0582 & 5.8 & 5.8 & -3.2 \\
\hline & 2009 & & 0.6862 & 0.8981 & -10.2 & -5.0 & \\
\hline & 2010 & & 0.9887 & 0.9549 & -4.5 & -9.2 & \\
\hline & 2008 & $\mathrm{~S} 4$ & 1.1029 & 1.3586 & 35.9 & 35.9 & 1.9 \\
\hline & 2009 & & 0.6596 & 0.9344 & -6.6 & 26.9 & \\
\hline & 2010 & & 1.1313 & 0.8345 & -16.6 & 5.9 & \\
\hline & 2008 & S6 & 1.3256 & 1.1303 & 13.0 & 13.0 & -5.4 \\
\hline & 2009 & & 0.8552 & 0.7206 & -27.9 & -18.6 & \\
\hline & 2010 & & 0.9088 & 1.0389 & 3.9 & -15.4 & \\
\hline \multirow[t]{3}{*}{ Average hedonic (5) } & 2008 & & & 1.1456 & 14.6 & 14.6 & -2.5 \\
\hline & 2009 & & & 0.8583 & -14.2 & -1.7 & \\
\hline & 2010 & & & 0.9436 & -5.6 & -7.2 & \\
\hline
\end{tabular}

Source: Own elaboration

number of paintings sold in auctions in the years 2007-2010. In the first step we estimate hedonic regressions to choose the models that best describe prices. However, it is difficult to evaluate the quality of models by the fitting parameters or parameter estimates interpretation, since the majority of variables represents qualitative features.

In the second step the hedonic art price indexes are calculated. We notice that specification of the models is crucial since it influences hedonic quality adjustment. Therefore price indexes are sensitive to the model specification, i.e. application of different hedonic models causes different values of the price index, and it is hard to decide which index describes the "true" price movement. Thus we propose to calculate the average hedonic indexes that include information from several models.

Considering the situation of the art market, one may notice that decline of art prices became visible in 2009, while the main index of the Warsaw Stock Exchange-WIG decreased by $51 \%$ (in 2008 in comparison to the previous year). As a result of the financial crisis in 2010, the decline of WIG was by $15 \%$ in comparison to the year 2007. In that period the decrease of art prices was only $12.8 \%$ for the naive index, and $7.2 \%$ for the average hedonic index. This observation justifies the opinion that art can be treated as a safe asset class. However, the 4-year period seems to be too short to make such comparisons. 


\section{Appendix}

Table 6 List of Polish painters whose artworks created the sample

\begin{tabular}{|c|c|c|c|c|c|c|}
\hline \multirow[t]{2}{*}{ No. } & \multirow[t]{2}{*}{ Author } & Count & $\begin{array}{l}\text { Value } \\
\text { [PLN] }\end{array}$ & $\begin{array}{l}\text { Average value } \\
{[\mathrm{PLN}]}\end{array}$ & $\begin{array}{l}\text { Year of } \\
\text { birth }\end{array}$ & \multirow[t]{2}{*}{$\begin{array}{l}\text { Year o } \\
\text { death }\end{array}$} \\
\hline & & \multicolumn{4}{|c|}{ of artworks sold in 2007-2010 } & \\
\hline 1 & $\begin{array}{l}\text { Chmieliński Stachowicz } \\
\text { Władysław }\end{array}$ & 55 & 648,200 & 11,786 & 1911 & 1979 \\
\hline 2 & Dominik Tadeusz & 46 & 608,000 & 13,217 & 1928 & - \\
\hline 3 & Dwurnik Edward & 63 & 431,300 & 6,846 & 1943 & - \\
\hline 4 & Erb Erno & 58 & 816,500 & 14,078 & 1890 & 1943 \\
\hline 5 & Kossak Wojciech & 60 & $2,027,500$ & 33,792 & 1856 & 1942 \\
\hline 6 & Wyczółkowski Leon & 61 & $3,848,300$ & 63,086 & 1852 & 1936 \\
\hline 7 & Hofman Wlastimil & 85 & $1,817,050$ & 21,377 & 1881 & 1970 \\
\hline 8 & Kossak Jerzy & 91 & $1,261,000$ & 13,857 & 1886 & 1955 \\
\hline 9 & Malczewski Jacek & 71 & $9,401,300$ & 132,413 & 1854 & 1929 \\
\hline 10 & Nikifor Krynicki & 79 & 196,400 & 2,486 & 1895 & 1968 \\
\hline 11 & Nowosielski Jerzy & 81 & $5,706,700$ & 70,453 & 1923 & 2011 \\
\hline
\end{tabular}

Source: Own elaboration

Table 7 Estimated models

\begin{tabular}{|c|c|c|c|c|c|c|c|}
\hline \multicolumn{2}{|l|}{ Variable variants } & \multirow{2}{*}{$\begin{array}{c}\text { Estimates } \\
2.7877\end{array}$} & \multirow{2}{*}{$\frac{\mathrm{S} 1}{* * *}$} & \multirow[t]{2}{*}{ Estimates } & \multirow[t]{2}{*}{$\mathrm{S} 2$} & \multirow{2}{*}{$\frac{\text { Estimates }}{2.7934}$} & \multirow{2}{*}{$\frac{\mathrm{S} 3}{* * *}$} \\
\hline Const & & & & & & & \\
\hline \multirow[t]{3}{*}{ Year } & YEAR_2007 & 0.0934 & & 0.0897 & & 0.0971 & \\
\hline & YEAR_2008 & 0.0758 & $* *$ & 0.1599 & $* *$ & 0.0768 & $* *$ \\
\hline & YEAR_2009 & 0.0145 & & 0.0814 & & 0.0154 & \\
\hline \multirow[t]{8}{*}{ Auction house } & AGRAART & 0.2945 & $* *$ & 0.3055 & $* *$ & 0.2989 & $* *$ \\
\hline & DESA & 0.1990 & & 0.2675 & $*$ & 0.2013 & \\
\hline & DESA_UNI & 0.4084 & $* * *$ & 0.4160 & $* * *$ & 0.4026 & $* * *$ \\
\hline & OKNA_SZTUKI & 0.4798 & $* * *$ & 0.5227 & $* * *$ & 0.4816 & $* * *$ \\
\hline & OSTOYA & 0.0998 & & 0.1643 & & 0.1032 & \\
\hline & POLSW & 0.8052 & $* * *$ & 0.8035 & $* * *$ & 0.7968 & $* * *$ \\
\hline & REMPEX & 0.0895 & & 0.1410 & & 0.0807 & \\
\hline & RYNEK_SZTUKI & 0.0172 & & 0.0531 & & 0.0080 & \\
\hline \multirow[t]{6}{*}{ Artist } & KOSSAK_J & -1.5906 & $* * *$ & -1.4183 & $* * *$ & -1.5896 & $* * *$ \\
\hline & KOSSAK_W & -0.8769 & $* * *$ & -0.6864 & $* * *$ & -0.8780 & $* * *$ \\
\hline & CHMIELISKI & -1.2274 & $* * *$ & -1.0203 & $* * *$ & -1.2266 & $* * *$ \\
\hline & DWURNIK & -2.2824 & $* * *$ & -2.1742 & $* * *$ & -2.2810 & $* * *$ \\
\hline & ERB & -1.0908 & $* * *$ & -0.8124 & $* * *$ & -1.0864 & $* * *$ \\
\hline & HOFMAN & -1.0883 & $* * *$ & -0.8475 & $* * *$ & -1.0862 & $* * *$ \\
\hline
\end{tabular}


Table 7 (continued)

\begin{tabular}{|c|c|c|c|c|c|c|c|}
\hline \multicolumn{2}{|l|}{ Variable variants } & \multirow{2}{*}{$\begin{array}{c}\text { Estimates } \\
0.3115\end{array}$} & \multirow{2}{*}{$\frac{\mathrm{S} 1}{* * *}$} & \multirow{2}{*}{$\begin{array}{c}\text { Estimates } \\
0.5349\end{array}$} & \multirow{2}{*}{$\frac{\mathrm{S} 2}{* * *}$} & \multirow{2}{*}{ Estimates } & \multirow{2}{*}{$\frac{\mathrm{S} 3}{* * *}$} \\
\hline & MALCZEWSKI & & & & & & \\
\hline & NIKIFOR & -1.3326 & $* * *$ & -0.8743 & $* * *$ & -1.3319 & $* * *$ \\
\hline & NOWOSIELSKI & -0.1185 & & 0.0723 & & -0.1186 & \\
\hline & DOMINIK & -1.9053 & $* * *$ & -1.8535 & $* * *$ & -1.9050 & $* * *$ \\
\hline Signature & & -0.0435 & & 0.0744 & & -0.0457 & \\
\hline \multirow[t]{8}{*}{ Technique } & watercolor & 0.1968 & & 0.5533 & $* * *$ & 0.1991 & \\
\hline & acrylic & 0.6975 & $* * *$ & 0.8912 & $* * *$ & 0.6998 & $* * *$ \\
\hline & gouache & 0.2849 & & 0.6414 & $* * *$ & 0.2918 & \\
\hline & oil & 0.8856 & $* * *$ & 1.0433 & $* * *$ & 0.8869 & $* * *$ \\
\hline & pencil & -0.2460 & & 0.2354 & & -0.2453 & \\
\hline & pastel & 0.4502 & $* *$ & 0.7456 & $* * *$ & 0.4525 & $* *$ \\
\hline & tempera & 0.6350 & $* * *$ & 0.9969 & $* * *$ & 0.6377 & $* * *$ \\
\hline & drawing ink & -0.5984 & $* *$ & -0.2753 & $* *$ & -0.5986 & $* *$ \\
\hline Price relation & & -0.0273 & & -0.04311 & & & \\
\hline Surface area & & 0.5646 & $* * *$ & 0.7482 & $* * *$ & 0.5636 & $* * *$ \\
\hline
\end{tabular}

Source: Own elaboration

Table 8 Estimated models

\begin{tabular}{|c|c|c|c|c|c|c|c|}
\hline \multicolumn{2}{|l|}{ Variable variants } & \multirow{2}{*}{$\begin{array}{c}\text { Estimates } \\
5.0405\end{array}$} & \multirow{2}{*}{$\frac{\mathrm{S} 4}{* * *}$} & \multirow{2}{*}{$\begin{array}{c}\text { Estimates } \\
5.0400\end{array}$} & \multirow{2}{*}{$\frac{\mathrm{S} 5}{* * *}$} & \multirow[t]{2}{*}{ Estimates } & \multirow[t]{2}{*}{ S6 } \\
\hline Const & & & & & & & \\
\hline \multirow[t]{3}{*}{ Year } & YEAR_2007 & 0.0067 & & 0.0075 & & 0.0067 & \\
\hline & YEAR_2008 & 0.0007 & & 0.0010 & & 0.0007 & \\
\hline & YEAR_2009 & 0.0019 & & 0.0021 & & 0.0019 & \\
\hline \multirow[t]{8}{*}{ Auction house } & AGRAART & 0.0834 & $* *$ & 0.0843 & $* * *$ & 0.0834 & $* *$ \\
\hline & DESA & 0.0844 & & 0.0848 & $* * *$ & 0.0844 & \\
\hline & DESA_UNI & 0.0550 & $* * *$ & 0.0536 & $* *$ & 0.0550 & $* * *$ \\
\hline & OKNA_SZTUKI & 0.0701 & $* *$ & 0.0707 & $* *$ & 0.0701 & $* *$ \\
\hline & OSTOYA & 0.0642 & $* * *$ & 0.0649 & $* * *$ & 0.0642 & $* * *$ \\
\hline & POLSW & 0.0717 & $* * *$ & 0.0697 & $* * *$ & 0.0717 & $* * *$ \\
\hline & REMPEX & 0.0606 & $* * *$ & 0.0584 & $* * *$ & 0.0606 & $* * *$ \\
\hline & RYNEK_SZTUKI & 0.0504 & $* *$ & 0.0481 & $* *$ & 0.0504 & $* *$ \\
\hline \multirow[t]{7}{*}{ Artist } & KOSSAK_J & -0.0566 & $* * *$ & -0.0565 & $* * *$ & -0.0566 & $* * *$ \\
\hline & KOSSAK_W & -0.0318 & & -0.0321 & $*$ & -0.0318 & \\
\hline & CHMIELISKI & -0.0601 & $* * *$ & -0.0600 & $* * *$ & -0.0601 & $* * *$ \\
\hline & DWURNIK & -0.1413 & $* * *$ & -0.1413 & $* * *$ & -0.1413 & $* * *$ \\
\hline & ERB & -0.0420 & $* *$ & -0.0409 & $* *$ & -0.0420 & $* *$ \\
\hline & HOFMAN & -0.0484 & $* *$ & -0.0479 & $* *$ & -0.0484 & $* *$ \\
\hline & MALCZEWSKI & -0.1007 & $* * *$ & -0.1003 & $* * *$ & -0.1007 & $* * *$ \\
\hline
\end{tabular}


Table 8 (continued)

\begin{tabular}{|c|c|c|c|c|c|c|c|}
\hline \multicolumn{2}{|c|}{ Variable variants } & \multirow{2}{*}{$\begin{array}{c}\text { Estimates } \\
-0.2556\end{array}$} & \multirow{2}{*}{$\frac{\mathrm{S} 4}{* * *}$} & \multirow{2}{*}{$\begin{array}{c}\text { Estimates } \\
-0.2553\end{array}$} & \multirow{2}{*}{$\frac{\mathrm{S} 5}{* * *}$} & \multirow{2}{*}{$\begin{array}{c}\text { Estimates } \\
-0.2556\end{array}$} & \multirow{2}{*}{$\frac{\mathrm{S} 6}{* * *}$} \\
\hline & NIKIFOR & & & & & & \\
\hline & NOWOSIELSKI & -0.0471 & $* * *$ & -0.0471 & $* * *$ & -0.0471 & $* * *$ \\
\hline & DOMINIK & -0.0594 & $* * *$ & -0.0596 & $* * *$ & -0.0594 & $* * *$ \\
\hline Signature & & -0.0038 & & -0.0043 & & -0.0038 & \\
\hline \multirow[t]{8}{*}{ Technique } & watercolor & -0.0155 & & -0.0149 & & -0.0155 & \\
\hline & acrylic & 0.0448 & & 0.0452 & & 0.0448 & \\
\hline & gouache & -0.0038 & & -0.0021 & & -0.0038 & \\
\hline & oil & 0.0561 & $* *$ & 0.0563 & $* *$ & 0.0561 & $* *$ \\
\hline & pencil & -0.0704 & $* *$ & -0.0701 & $* *$ & -0.0704 & $* *$ \\
\hline & pastel & 0.0336 & & 0.0341 & & 0.0336 & \\
\hline & tempera & 0.0296 & & 0.0303 & & 0.0296 & \\
\hline & drawing ink & -0.0171 & & -0.0172 & & -0.0171 & \\
\hline \multicolumn{2}{|c|}{ Surface area $^{2}$} & 0.0484 & $* * *$ & 0.0484 & $* * *$ & 0.0484 & $* * *$ \\
\hline \multicolumn{2}{|c|}{ Price relation } & -0.0065 & & & & -0.0065 & \\
\hline \multicolumn{2}{|c|}{ Artist's living status } & & & & & 5.0405 & $* * *$ \\
\hline
\end{tabular}

Source: Own elaboration

Open Access This article is distributed under the terms of the Creative Commons Attribution License which permits any use, distribution, and reproduction in any medium, provided the original author(s) and the source are credited.

\section{References}

Campbell, R.A.J. (2004). The art of portfolio diversification. LIFE/Maastricht University Working Paper, viewed 1 July 2008, http://www.fdewb.unimaas.nl/finance/faculty/Campbell/images/Art\%20Investment.pdf.

Campbell, R. A. J. (2008). Art as a financial investment. The Journal of Alternative Investments, 10(4), 64-81. Candela, G., Figini, P., \& Scorcu, A. E. (1997). A price index for art market auctions. An application to the Italian market of modern and contemporary oil paintings. Journal of Cultural Economics, 21, 175-196.

Candela, G., Figini, P., \& Scorcu, A. E. (2004). Price indices for artists - a proposal. Journal of Cultural Economics, 28(4), 285-302.

Chanel, O., Gérard-Varet, L.-A., \& Ginsburgh, V. (1994). Prices and returns on paintings: an exercise on how to price the priceless. The Geneva Papers on Risk and Insurance Theory, 19, 7-21.

Deloitte (2013). Rynek sztuki. Sztuka rynku, is a part of http://www.deloitte.com/assets/Dcom-Poland/Local\% 20Assets/Documents/Raporty,\%20badania,\%20rankingi/pl_Art\&Banking_PL.pdf. Accessed 12 November 2013 (in Polish).

Frey, B. S., \& Cueni, R. (2013). Why invest in art? The Economist's Voice, 10(1), 1-6.

Frey, B. S., \& Pommerehne, W. W. (1988). Is art such a good investment? The Public Interest, 91, 79-86.

Frey, B. S., \& Pommerehne, W. W. (1989a). Art investment: an empirical inquiry. Southern Economic Journal, 56(2), 396-409.

Frey, B. S., \& Pommerehne, W. W. (1989b). Muses and markets. Explorations in the economics of the arts. Oxford: Basil Blackwell.

Gajewski, M., Potocki, T. (2013). Skate's focus: Poland's art market the rising star of central Europe, report created by Skate's Art Market Research Art \& Business Magazine S.A., Skate's, LLC, New York, NY, 
USA, skatesart.files.wordpress.com/2013/03/skates-focus-polands-art-market.pdf. Accessed 29 January 2014.

Ginsburgh, V., Mei, J., \& Moses, M. (2006). The computation of prices indices. In Handbook of the economics of art and culture (pp. 947-979). Amsterdam: North Holland. chapter 27.

Goetzmann, W. N., Renneboog, L., \& Spaenjers, C. (2011). Art and money. American Economic Review, 101, $222-226$.

Higgs, H. (2012). Australian art market prices during the global financial crisis and two earlier decades. Australian Economic Papers, 51(4), 189-209.

Hsieh, S., Lee, J., \& Tzeng, L.Y. (2010). Art as an investment: Empirical study of Asian contemporary and Chinese 20th century modern art, international conference on finance department of finance, National Taiwan University, December 10-11, 2010, discussion paper. http://www.fin.ntu.edu.tw/ conference/ conference2010/proceedings/proceeding/11/11-1(A40).pdf, viewed 7.11.2013.

Kraeuss1, R., \& Logher, R. (2010). Emerging art markets. Emerging Markets Review, 11(4), 301-318.

Kraeussl, R., \& van Elsland, N. (2008). Constructing the true art market index - a novel 2-step hedonic approach and its application to the German art market, CFS working paper, Center for Financial Studies Frankfurt University, No. 2008/11, Germany.

Kraeussl, R., \& Wiehenkamp, C. (2012). A call on art investments. Review of Derivatives Research, 15(1), 123.

Lucińska, A. (2012). Rozwój artystyczny malarzy a ceny obrazów na polskim rynku sztuki in: Zarzecki D. (ed.), Finanse, Rynki Finansowe, Ubezpieczenia Nr 51, Zeszyty Naukowe Uniwersytetu Szczecińskiego, Szczecin, Poland, 715-725 (in Polish).

Mc Andrew, C. (2013). TEFAF art market report 2013 the global art market, with a focus on China and Brazil. Holland: The European Fine Art Foundation, TEFAF Maastricht.

Mei, J., \& Moses, M. (2002). Art as an investment and the underperformance of masterpieces. American Economic Review, 92(5), 1656-1668.

Nesheim, L. (2006). Hedonic price functions. London: CEMMAP.

Pesando, J. E. (1993). Art as an investment: the market for modern prints. American Economic Review, 83(5), 1075-1089.

Radwan, Ł. (2004). Gdzie jest Rafael?, Wprost24/2004 (1124), http://www.wprost.pl/ar/61314/ last viewed 12.12.2013 (in Polish).

Renneboog, L., \& Spaenjers, C. (2013). Buying beauty on prices and returns in the art market. Management Science, 59(1), 36-53.

Triplett, J. (2006). Handbook on hedonic indexes and quality adjustments in price indexes, special application to information technology products. Paris: OECD Publishing.

World Wealth Report 2012 from Capgemini and RBC Wealth Management, http://www.capgemini.com/ thought-leadership/world-wealth-report-2013-from-capgemini-and-rbc-wealth-management. Accessed 12 November 2013.

Worthington, A. C., \& Higgs, H. (2003). Art as an investment: short and long-term comovements in major paintings markets'. Empirical Economics, 28, 649-668.

Worthington, A. C., \& Higgs, H. (2004). Art as an investment: risk, return and portfolio diversification in major painting markets. Accounting and Finance, 44, 257-271. 